\title{
Behavioral Analysis of Credit Card Users in a Developing Country: A Case of Bangladesh
}

\author{
Leo Vashkor Dewri ${ }^{1}$, Md. Rashidul Islam ${ }^{1} \&$ Netai Kumar Saha ${ }^{1}$ \\ ${ }^{1}$ Department of Business Administration, East West University, Dhaka, Bangladesh \\ Correspondence: Leo Vashkor Dewri, Department of Business Administration, East West University, Dhaka, \\ Bangladesh. E-mail: leodewri81@gmail.com
}

Received: January 30, 2016

Accepted: February 23, 2016

Online Published: March 28, 2016

doi:10.5539/ijbm.v11n4p299

URL: http://dx.doi.org/10.5539/ijbm.v11n4p299

\begin{abstract}
Economic structure plays a vital role to drive consumer spending attitudes in different countries. Bangladesh is considering as a lower middle income country that indicates citizen of Bangladesh doesn't have significant ability to increase their spending habits. Bangladeshis' are experiencing credit card not more than two decades. Also accepting credit card by wider merchants in lieu of payment is also comparatively new practice in Bangladesh. In this regard, the financial institutions / credit card issuers and retailers are experiencing new spending behaviors of credit card holders. Primarily, the research attempts to investigate behavioural usage patterns of credit card users in the emerging economics. Secondly, how the external factors are influencing the credit card users to use credit cards in their day-to-day life. To conduct the research 500 credit card holders are approached of which 393 credit card holders responded and been analyzed. The research concludes that there is significant relationship among - earnings and using full credit limit; different age group has diverse tendency to use credit card and repayment attitudes; profession and usage behavior of credit card; e-repayment attitudes to pay bill by different age groups. This study also reveals that there is no-significant relationships among gender differences is not an concern for using credit card; single credit card features are truly not motivating credit card users to use credit card frequently; interestingly external factors (like: discount offers or other card facilities) are not only driving force to encourage credit card holders to use their credit cards frequently. The study recommends fragmenting the credit card market in Bangladesh based on consumer demographics and attitudes towards using short/midterm debt.
\end{abstract}

Keywords: credit card, demography, attitude toward debt

\section{Introduction}

Numbers of Credit card holdings and usages have been increasing significantly in recent decades across the globe. This trend's is reaching popularity as a preferred mode of payment for shopping and other various services like: utility bill payments, online payment across the border due to convenient method of payment in lieu of cash, checks, pay order or other way of payment (Themba \& Tumedi, 2012; Abdul-Muhmin et al., 2007). Credit card allows its holders to purchase or obtain any goods or services without paying any form of cash by accessing to credit and therefore removing the burden of carrying cash (Rutherford \& DeVaney, 2009). In spite of these benefits, credit card holders and its usage behaviour is associated with amount of consumers debt as well as uncontrolled or unplanned spending (KurtuluŞ, 2006; Thomas et al., 2010; Norum, 2008). Research evidence reflects that credit card related debt is rising significantly since last recent decade due to substantial share of household spending across the globe (Arabzadeh et al., 2015; Foscht et al., 2008).

The credit card ownership and usage behaviour significantly depends on demographic characteristics of users such as sex, age, profession, religious believe, education level, income, marital status, culture and attitude towards debt (Kaynak et al., 1995; Wickramasinghe \& Gurugamage, 2009). Usually credit card companies issue credit cards or revolving credit to the pre-determined groups of individuals those typically have upper income, well educated and hold highly designated occupations during the growth stage of credit card markets (Adcock et al., 1997). Furthermore, research indicates that the multi number of credit cards owned by an individual's increases the frequency of use the credit during purchases (Gan et al., 2008; Abdul-Muhmin \& Umar, 2007).

Empirical research also reveals that due to convenient way of payment to purchase goods and servicers the card holders have greater tendency to avail multiple credit cards as revolving credit (Wickramasinghe \& Gurugamage, 
2009; Kaynak et al., 1995).

Most of the studies on behaviour of credit card users are conducted based on both developed and developing nations i.e. China, Cyprus, Malaysia, India, USA etc in recent time. However, very least research has been conducted on least developing courtiers like Bangladesh. This market is experiencing approximate 20 years of using the credit card and the tendency is growing significantly. In this regards, the usage patterns of credit card users hugely differ from structured (developed), semi-structured (semi-developed) and emerging markets.

The primary objective of this study is to investigate behavioural usage patter of credit card users in the emerging economics like Bangladesh. Secondly, investigate - how the external factors like various promotional events by retailers, providing credit repayment flexibilities are influencing the credit card users to use credit cards in their day-to-day life. Empirical research on psychological, neurological and economic evidence research on present bias and overall impatience has critical implications for the financial decisions of borrowing and default. Deciding how much to borrow, particularly on credit cards, is closely linked to the instant gratification of card purchases

\section{Literature Review}

\subsection{Earning Capability and Using Credit Limit}

According to Kim and DeVaney (2001) using credit card depends on the general attitude of consumers feeling and social norms. Purchasing decision is influenced by lifestyle and surrounding people expectations on consuming goods or services, generally termed as social norms (Conner \& Armitage, 1998). However, current consumption of goods or services are likely depends on the permanent income and anticipation of higher future income (Friedman, 1957). Generally, individuals who desire to hold a similar standard of living with peer groups and expect higher income prospect will borrow in order to fit into place in behavior expected by their peer groups (Rutherford \& DeVaney, 2009). Moreover, when individuals want to conform to the social norms, they are more likely to acquire commodities mimic by others, and the desired consumption can be availed by credit cards since the purchase can be charged later on (Kaynak et al., 1986; Roberts \& Jones, 2001). In addition, consumer spending behaviour toward luxury items and vacation activities depends on higher earning capabilities, also directed by social pressure (Katz, 1997). Based on the conclusions of these studies, the next hypothesis is developed.

Hypotheses 1: Higher earners have greater tendency to use revolving credit frequently.

\subsection{Demographic Behavioral Patterns and Using Revolving Credit}

\subsubsection{Age and Credit Card Usage Behaviour}

Attitude of using credit cards depends on the users' age, education, profession and gender (Muhmin \& Umar, 2007; Wickramasinghe \& Gurugamage, 2009). According to the planned behavior theory the credit consumption behavior depends on earning capabilities, toward risk tolerance attitude, and the planning horizon (e.g., Godwin, 1998; Hazembuller, Lombardi, \& Hogarth, 2007; Kim \& DeVaney, 2001). However, above mention qualities differs among individual users based on their demographic attributes like: credit card ownership and usage are largely influenced by demographic characteristics of users such as gender, age, education level, income, marital status, ethnic background, culture and attitude towards debt (Muhmin \& Umar, 2007; Wickramasinghe \& Gurugamage, 2009). Empirical research indicates that high income countries have greater tendency to use revolving credit compare to low income countries (Themba \& Tumedi, 2012) like Bangladesh. Similarly, there is a strong difference of using credit cards between youngstars' (age 25-35) and middle (age 36-55) and aged (age $55+$ ) people. In addition to that, earning capabilities of senior citizens (age 55+) and spending attitude may differ between structured and unstructured market of credit card. It is also observing that the younger and middle aged people have greater tendency to use credit card to fulfill their desire compare to their seniors'. Therefore, we want to test the below mentioned hypothesis in respect of Bangladesh.

Hypotheses 2: Senior citizens have lower tendency to use credit card frequently than young stars and middle and people.

\subsubsection{Age and Credit Bill Repayment Attitudes}

Rutherford and DeVaney (2009) identify two types of credit card users based on their credit card payment attitudes. The users who repay full amount of credit balance on regular basis at the end of the month are known as convenience users (Rutherford \& DeVaney, 2009). Conversely, credit card users, those who repay their credit balance partially after receiving the credit card statement at the end of the month, are treated as revolvers (Rutherford \& DeVaney, 2009) or inconvenience users. Empirical studies evidence that using credit card and repay debt depends on general credit attitude, risk tolerance attitude, and the planning horizon (e.g., Godwin, 
1998; Hazembuller, Lombardi, \& Hogarth, 2007; Kim \& DeVaney, 2001). General credit attitude and risk tolerance attitude are determining by emotional reaction of the credit card users inner feelings (Rutherford \& DeVaney; 2009). Conversely, planning horizon is measured based on rational attitude towards credits which derived from previous experiences on using credit. In this regard, Schwarz (2003) argues that consumer decision making process depends on age and related experience as different age groups have different set of value (Peterson, 2007). Kim and DeVaney (2001) argue that there is negative correlation or curvilinear relationship between age and outstanding credit balances as young consumers are faced with financial difficulties due to lower-earnings and high expenses of to maintain the raising family, these reasons are the major driving force to borrow from credit card to maintain their regular livelihood. Kim and DeVaney (2001) also explore the facts that until age 37 credit card users are more revolver than seniors and decrease afterward. The study also reveals that the generation effect, where the younger generation is using more credit without any hesitation than the senior counterpart. Therefore, it is rationalising that younger are more likely to be inconvenience users rather than seniors. In this regard, the hypothesis would be:

\section{Hypothesis 3: Senior citizens are convenience users than younger.}

\subsubsection{Gender and Credit Card Usage Behavior}

Credit card ownership and usage differs on male and female (Themba \& Tumedi, 2012). Females are generally owns and use less revolving credit (Khare et al., 2011) than male as females are less risk tolerance(Dewri, Islam, \& Zamman, 2015). On the other hand, in the middle-eastern countries female like to hold more credit card than male as this people akin to do shopping compare than other part of the world (Muhmin \& Umar, 2007; Themba \& Tumedi, 2012; Kaynak et al., 1995). Interestingly Robb (2011) concluded that college going females are more likely to engage in risky credit card behavior than males. However, shopping behavior by using credit cards may differ with sexual characteristics in regard to the type of products and services (Themba \& Tumedi, 2012; Kaynak \& Harcar, 2001). Furthermore, female be inclined to use credit cards to acquire home appliances, garments and personal belongings whereas men use them for electronics, entertainment, travel and food (Kaynak \& Harcar, 2001). The gender attitude in developing country like Bangladesh differs than India, middle-eastern and western countries due to culture, religious believes, earning capabilities and credit availability. Therefore, we would like to test this hypothesis that:

Hypothesis 4: Females' are using less revolving credit than male.

\subsubsection{Profession and Usage Behavior of Credit Card}

According to Themba and Tumedi (2012) convenience users of credit card suppose to be older age, advanced educational level, higher income, married and those who hold a more conservative view towards debt. Similarly, designated profession like: university teachers, doctors, lawyers, business and IT consultants as well as executives of multinational companies generally draw higher earnings compare to the counterparts like: public service holders, school and college teachers, service holders of local private companies etc. Designated professions have greater access to the revolving credit as credit limits normally supported by their earnings. Conversely, undesignated professions' have very low or limited access to the revolving credit. This is probably financial institutions believe that lower earners are comparatively very risk to bear the credit and repay their debt. But the argument is lower earners are not always credit defaulter and sometimes their trustworthy then the counterparts (See: loan recovery rate of Grameen Bank).

Therefore the hypothesis we are going to test that:

Hypothesis 5: Profession differentiation has variation in using behavior.

\subsubsection{Age and Credit Card Bill Payment Methods by Different Medium}

According to Aaron Smith (2014) developed countries like USA seniors citizens are comparatively late adopters of global technology than the younger, although seniors attempting to educating themselves to adopt modern technologies. Obviously, modern technology making life easier as it does by various financial services like credit card, ATM, e-banking etc. Typically there is a senior group of people who incline toward younger and have higher education, or more financially affluent. As this group of people are more extensively knowledgeable on different technology, and also has a very optimistic view on the benefits of modern technology. Conversely, other group of seniors is psychologically and financially reluctant to adapt to modern technology and services (Pew Research Center, USA). As a result, technologically adverse senior citizens are logically discounted from the benefit of global technology. On the other hand, information technology plays an important role to change the habits of life style in terms of shopping, trading, education and so on. This adaptation is advanced to young people than senior citizens. In this regard, the hypothesis is: 
Hypothesis 6: Younger prefer to use modern technology to repay their credit card bill.

\subsection{Credit Card Features and Usages Behavior}

According to the Economic Man theory a human generally acts rationally and with complete knowledge, but completely from self-expectation and the pursuit to acquire maximum personal commodity. This theory indicates that consumers should have all available consumption options and be capable to rate and chose the best alternative (Schiffman, 2007). However, this theory is no longer valid in the real world (Simon, 1997; Kahneman, 1979). Consequently, consumers generally seek satisfactory rather than optimum choices.

In addition, generally using revolving credit depends on various credit features are offering by financial institutions to their clients. It is being observing that during different festivals card companies are offering different types of discounts and cash back offers. This offers normally attracts card users to use their credit to satisfy their desire. Similarly, financial institutions some time offers cash advance, fund transfer facilities, funding for progressive work (like: down payment to purchase car, property, etc.), buy now pay later (Payflex) for acquiring household or life style items, holiday, health care to their clients. But the question is: how frequent the card holders are using their credit card to satisfy their needs? Therefore we are pursuing to test the following hypothesis.

Hypotheses 7: Various credit features attract credit card users to use credit card frequently.

\subsection{Behavioral Influence to Use a Credit Card}

Empirical studies evidence that behavior is normally influenced by external factors like: actions, thoughts and feelings (Watson \& Rayner, 1920). According to the theory of Classical conditioning (Watson \& Rayner, 1920) and operant conditioning (Skinner, 1938) logical positivism can be applied to study consumer behavior (Eysenck et al., 2000). Classical Behaviorism theory suggest that to determine consumer behavior only internal factors are considered. While Operant conditioning explain the situation how a individual behave with the changes of external environment (Skinner, 1938).

Self-desire to hold a commodity mostly depends on individuals' internal thoughts and feelings as someone may desire to buy a luxury item like car, which is motivated by him/herself. In this regard, this behavioral approach does not consider any external pressure. While, individuals are motivated to acquire goods or services as per Maslow's hierarchy need theories (Gable, The Third Force). In addition, to fulfill the desire to hold goods and services greatly influenced by peer group consumption, various offering by retailer and financial institutions, as well as social status. These are theoretically explained but we would like to examine empirically. Therefore, the hypothesis would be:

Hypotheses 8: External factors are more influencing credit card users to spend money through credit cards.

\section{Research Methodology}

\subsection{Sampling Design}

Sampling is the selection of some elements form a population (Cooper \& Schindler, 2003). This is a very complex process to conduct survey on large sample size (Cooper \& Schindler, 2003; and Cameron \& Price, 2009). For this reason, the number of sample selection is very important among responsiveness, sample size and time availability of data analysis (Smith, 2003). Generally, sample size is decided by the researcher based on his/her judgement because the undertaken sample size reveals the expected level of precision. According to the Central Bank of Bangladesh there are about four Million credit cardholders prevailing in Bangladesh. Because of the large size of population, we have attempted to 500 credit card holders and received response from 390 respondents. This 500 sample size seems reasonable as previous researchers followed similar strategy (Islam et at., 2013; Naser et al., 2003; Pricewatercoopers, 2007; Schwarzkopf, 2007).

\subsection{Data Collection}

To reveal the demographic pattern and usage behavior of credit card users puzzles, we conducted the survey on Bangladeshi credit card users group to explore on their profession, salary, usages pattern of credit card, preferred payment method of credits, external and internal influence of using credit card and self-esteemed. The credit card holders' portfolio is obtainable, that permit us to be familiar with the survey reaction and examine a range of physiographic, behavioral finance on revolving credit and control behavior in using credit theories further. We exclude the corporate or business credit card which is basically own by business organization in this study as their usage pattern are completely different than individuals.

Data is collected by using social media, email as well as visiting various corporate offices by following personal references. The target respondents were individual credit card users in Bangladesh. 


\subsection{Survey Instrument}

Both the psychographic and demographic variables chosen in this study to judge behavioral pattern of credit card users which are identified from literature and included factors namely: profession and related salary, time consciousness, life style, various features of credit card that influences using behavior, self-esteem, exposure to advertisement and gregariousness. The questionnaires are developed by considering demographic and behavioral pattern of the users. The demographic patter addresses: Gender, age, profession and designated salary. Simultaneously, the behavioral pattern considers: Purpose of using credit card, How frequently using credit card, Using credit limit, Repayment amount attitude, Features of credit card, Payment process and Behavioral influence to use a credit card. We used another variable that is Credit limit which depends on Salary. The respondents are asked 12 questions and chose answers from given options. Later on variables are converted as sequential numbers for analysis purposes, also provided a blank space to have their unique opinions, if have any.

Credit card holders basically reside and work either in Dhaka or Chittagong to form the target sample in this study as these two cities are the largest and most of the credit cardholders belong to these cities. Questionnaires distributed to respondents by asking beforehand whether they are using any credit card or not. After responding positively; the questionnaires distributed to them. A sample study conducted to examine whether target participant clearly understand the questionnaires.

\subsection{The Questionnaire}

Primary data can be collected through by using various methods like: interviews, questionnaire or both. Interview method can guide the interview and explain the tricky questions and produce qualitative information (Price \& Cameron, 2009; Bryman \& Bell,2003). The disadvantage of the interview technique is difficult to manage due to number of reasons like meeting, scheduling, timing etc. However, questionnaires can be sent by social media (like: face book, twitter etc.) or email to the target respondent. The significant advantage of questionnaire method is the respondent can be reached to the wider geographical area (Blumberg and Schidler, 2008). But the major difficulty of questionnaire technique is it sometimes provides erroneous information due to misunderstanding of the questions by the respondent. As a consequence of that we chosen questionnaires with semi structured interview method to get more accurate data from respondents.

\subsection{Quantitative Analysis}

Initially, we use statistical tools to experiment the credit card consumer usage behavior by modeling the relationship between demography and physiographic attributes of the Bangladeshi credit cardholders. These attributes include age, gender, profession, income, and usage pattern of credit card.

Last part of the analysis, the frequencies and percentages of responses are found which are made to find out whether the responses from demographic groups are significantly different or not.

\section{Analysis and Findings}

\subsection{Relationship between Earnings and Using Credit Limit}

Table 1 describes the relationship between earnings and using revolving credit irrespective of gender. The study represents that most of the users are using their partial credit limits $(62 \%)$, whereas $38 \%$ users are using their full credit limit. However, lower earners (BDT. 21-80k) have greater tendency to use their partial credit limit than counterpart. According to the users' point of view, if they use beyond their repayment capacity they will be struggling to repay the debt in the future. This study further revels that $66 \%$ of highest earners are using more revolving credit than the comparatively lower earners (BDT. 21k - 80k).

Table 1. The relationship between earnings and using revolving credit irrespective of gender

\begin{tabular}{llllll}
\hline $\begin{array}{l}\text { Earnings } \\
\text { BDT }\end{array}$ & $\begin{array}{l}\text { Full limit } \\
\text { users }\end{array}$ & Percentage (\%) & $\begin{array}{l}\text { Partial } \\
\text { users }\end{array}$ & Percentage (\%) & $\begin{array}{l}\text { Total } \\
\text { Users }\end{array}$ \\
\hline $21-40 \mathrm{k}$ & 13 & 9 & 23 & 9 & 36 \\
$41-80 \mathrm{k}$ & 32 & 22 & 64 & 26 & 96 \\
$81-120 \mathrm{k}$ & 11 & 7 & 78 & 32 & 89 \\
$121 \mathrm{k}+$ & 92 & 62 & 80 & 33 & 172 \\
Overall & $\mathbf{1 4 8}$ & $\mathbf{3 8}$ & $\mathbf{2 4 5}$ & $\mathbf{6 2}$ & $\mathbf{3 9 3}$ \\
\hline
\end{tabular}

Frequency Table: Relationship between earnings and using revolving credit.

The Results on Linear regression and Testing $\mathrm{H} 1$ 
After conducting the ANOVA test on depended variable (Earnings) and independent variable (Using credit limit) it is indicating that there is a significant relationship between earnings and using the credit limit. As the $p$ value is 0.005 which is less than .05 , thus, the test supports the hypothesis 1 and proves that the heights earners have greater tendency to use more revolving credit.

Table 2. Statistics

\begin{tabular}{|c|c|c|c|c|c|c|c|}
\hline \multicolumn{8}{|c|}{ ANOVA $^{b}$} \\
\hline \multicolumn{2}{|l|}{ Model } & Sum of Squares & df & Mean Square & \multicolumn{2}{|l|}{$\mathrm{F}$} & Sig. \\
\hline \multirow{3}{*}{1} & Regression & $7.983 \mathrm{E} 11$ & 1 & $7.983 \mathrm{E} 11$ & 7.972 & & \\
\hline & Residual & $3.915 \mathrm{E} 13$ & 391 & $1.001 \mathrm{E} 11$ & & & \\
\hline & Total & $3.995 \mathrm{E} 13$ & 392 & & & & \\
\hline \multicolumn{8}{|c|}{ a. Predictors: (Constant), Using credit limit. } \\
\hline \multicolumn{8}{|c|}{ b. Dependent Variable: Salary. } \\
\hline \multicolumn{8}{|c|}{ Coefficients $^{\mathrm{a}}$} \\
\hline \multirow[t]{2}{*}{ Model } & & \multicolumn{2}{|c|}{ Unstandardized Coefficients } & \multicolumn{2}{|c|}{$\begin{array}{l}\text { Standardized } \\
\text { Coefficients }\end{array}$} & \multirow[t]{2}{*}{$-\mathrm{t}$} & \multirow[t]{2}{*}{ Sig. } \\
\hline & & $\mathrm{B}$ & Std. Error & Beta & & & \\
\hline \multirow{2}{*}{1} & (Constant) & 168561.224 & 20216.182 & & & 8.338 & .000 \\
\hline & Using credit limit & 93016.478 & 32943.107 & .141 & & 2.824 & .005 \\
\hline
\end{tabular}

a. Dependent Variable: Salary

\subsection{Demographic Patterns and Credit Card Usage Behavior}

\subsubsection{Age and Frequency of Using Credit Card}

Frequency table: Age and using of revolving credit - revels that middle age (36-55) people have greater tendency to use credit card more frequently 48\% than young stars (age 25-35) 32\%. Interestingly it has been observing that young people in the Bangladesh has comparatively less tendency to use credit card frequently than structured market of the credit card due to greater variance of socio-economic factors. On the other hand, senior citizens (age 55+) are comparatively using (12\%) less credit cards.

Table 3. Age and using of revolving credit

\begin{tabular}{llllllll}
\hline Age & Very frequently & $\begin{array}{l}\text { Percentage } \\
(\%)\end{array}$ & $\begin{array}{l}\text { Frequently } \\
\text { 5> }\end{array}$ & $\begin{array}{l}\text { Percentage } \\
(\%)\end{array}$ & $\begin{array}{l}\text { Low frequently } \\
<5\end{array}$ & $\begin{array}{l}\text { Percentage } \\
(\%)\end{array}$ & Total \\
\hline $25-35$ & 23 & 15 & 101 & 68 & 25 & 17 & 149 \\
$36-45$ & 42 & 22 & 115 & 60 & 34 & 18 & 191 \\
$46-55$ & 0 & 0 & 33 & 89 & 4 & 11 & 37 \\
$55+$ & 0 & 0 & 5 & 31 & 11 & 69 & 16 \\
Overall & $\mathbf{6 5}$ & & $\mathbf{2 5 4}$ & & $\mathbf{7 4}$ & & $\mathbf{3 9 3}$ \\
\hline
\end{tabular}

Frequency Table: Age and using of revolving credit.

\section{The Results on Linear regression and Testing $\mathrm{H} 2$}

The result of the ANOVA test on depended variable (How Frequently Using the credit) and independent variable (Age) is indicating that there is a significant relationship between earnings and using the credit limit. As the $p$ value is 0.046 which is less than .05 , thus, the test support the hypothesis 2 and demonstrate that the young and middle aged citizens have greater tendency to use more revolving credit than the seniors'. 
Table 4. ANOVA test result

\begin{tabular}{|c|c|c|c|c|c|c|}
\hline \multicolumn{7}{|c|}{ ANOVA $^{b}$} \\
\hline Model & & Sum of Squares & $\mathrm{df}$ & Mean Square & $\mathrm{F}$ & Sig. \\
\hline \multirow[t]{3}{*}{1} & Regression & 250.450 & 1 & 250.450 & 4.026 & $.046^{\mathrm{a}}$ \\
\hline & Residual & 24325.784 & 391 & 62.214 & & \\
\hline & Total & 24576.234 & 392 & & & \\
\hline
\end{tabular}

a. Predictors: (Constant), How frequently using credit card

b. Dependent Variable: Age

\begin{tabular}{|c|c|c|c|c|c|c|}
\hline \multicolumn{7}{|c|}{ Coefficients $^{\mathrm{a}}$} \\
\hline \multirow{3}{*}{\multicolumn{2}{|c|}{ Model }} & \multirow{2}{*}{\multicolumn{2}{|c|}{ Unstandardized Coefficients }} & \multirow{2}{*}{\multicolumn{2}{|c|}{$\begin{array}{l}\text { Standardized } \\
\text { Coefficients }\end{array}$}} & \multirow[b]{3}{*}{ Sig. } \\
\hline & & & & & & \\
\hline & & $\mathrm{B}$ & Std. Error & Beta & $\mathrm{T}$ & \\
\hline \multirow[t]{2}{*}{1} & (Constant) & 37.132 & .792 & & 46.882 & .000 \\
\hline & How frequently using credit card & 1.343 & .670 & .101 & 2.006 & .046 \\
\hline
\end{tabular}

\subsubsection{Age and Credit Bill Repayment Attitude}

Table 5 is showing the frequency of age and credit card bill repayments behavior of credit card users. It indicates that younger users' (53\%) have greater tendency to repay their bill partially than senior citizens. Interestingly, there is no significant differentiation between credit revolver (45\%) and full repayment (52\%) for middle aged users. This study further indicates that most of the younger are inconvenience users whereas the majority of the middle aged and senior citizens are convenience users (Rutherford \& DeVaney; 2009).

Table 5. The frequency of age and credit card bill repayments behavior of credit card users

\begin{tabular}{llllll}
\hline Age & Partial repayment & $\begin{array}{l}\text { Percentage } \\
\text { \% }\end{array}$ & Full repayment & $\begin{array}{l}\text { Percentage } \\
\%\end{array}$ & Total \\
\hline $25-35$ & 109 & 53 & 40 & 21 & 149 \\
$36-45$ & 92 & 45 & 99 & 52 & 191 \\
$46-55$ & 3 & 1 & 34 & 18 & 37 \\
$55+$ & 0 & 0 & 16 & 8 & 16 \\
Overall & $\mathbf{2 0 4}$ & $\mathbf{5 2}$ & $\mathbf{1 8 9}$ & $\mathbf{4 8}$ & $\mathbf{3 9 3}$ \\
\hline
\end{tabular}

Frequency Table: Age and credit repayment attitude.

\section{The Results on Linear regression and Testing $\mathbf{H} 3$}

The below ANOVA test result is reflecting that there is significant relationship between age (independent variable) and repayment amount attitude (depended variable). As the p value is 0.000 which is less than .05 , thus, the result supports the hypothesis that there is a significant difference between age and repayment amount approach in Bangladesh. The result indicates that younger are using more revolving credit than seniors. 
Table 6. ANOVA test result

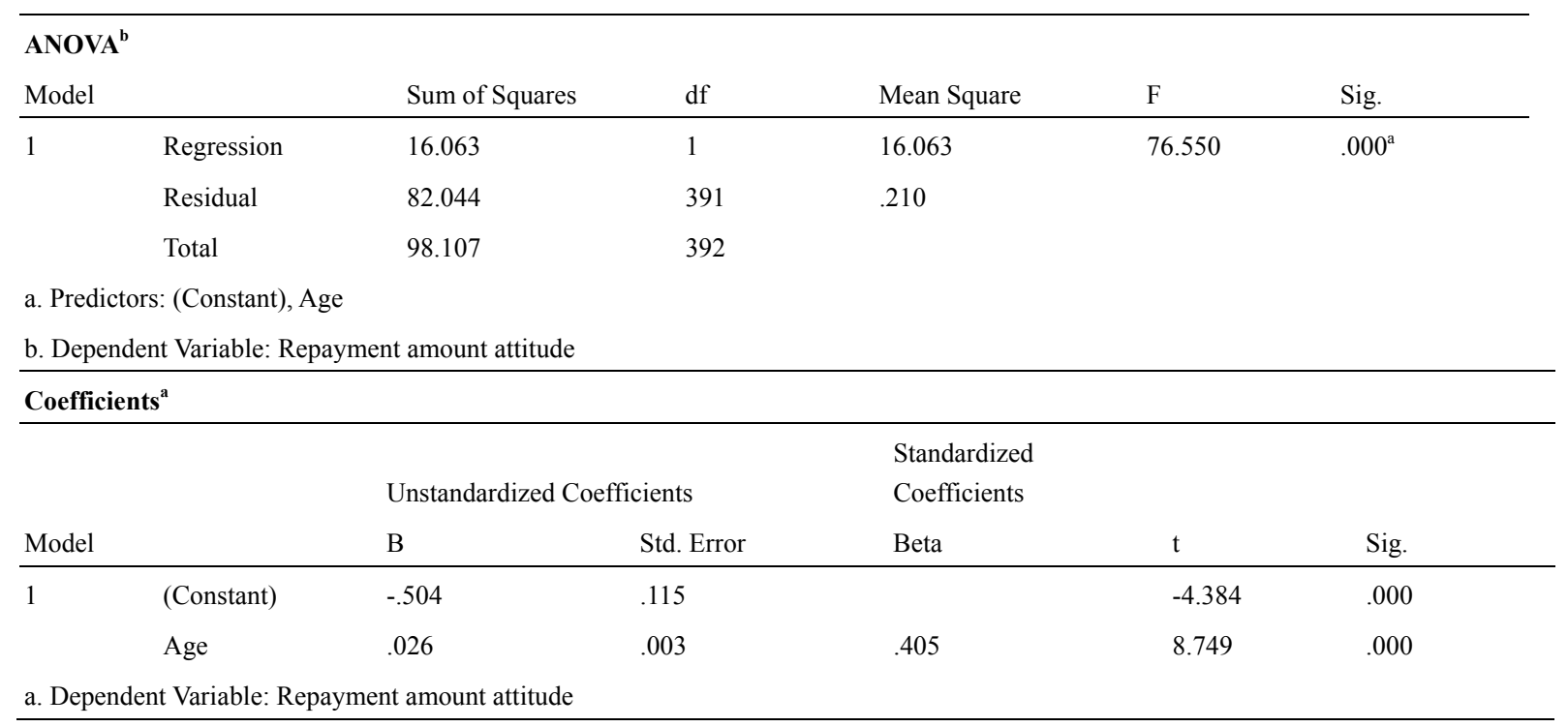

\subsubsection{Gender and Using Credit Limit}

Below frequency table is reflecting the credit using behaviors of gender demography that indicates $46 \%$ users of credit card are using full credit whereas 54\% are using partial credit limit. However, female credit cardholders are using full credit limit (67\%) than the counterpart of male $43 \%$. Conversely, male users $(57 \%)$ have greater tendency to use their credit limit than their counterpart $(33 \%)$.

Table 7. The credit using behaviors of gender demography

\begin{tabular}{lllll}
\hline Gender & Using Full Credit & $\begin{array}{l}\text { Percentage } \\
(\%)\end{array}$ & Using Partial Credit & $\begin{array}{l}\text { Percentage } \\
(\%)\end{array}$ \\
\hline Male & 147 & 43 & 195 & 57 \\
Female & 34 & 67 & 17 & 33 \\
Overall & $\mathbf{1 8 1}$ & $\mathbf{4 6}$ & $\mathbf{2 1 2}$ & $\mathbf{5 4}$ \\
\hline
\end{tabular}

Frequency Table: Gender and credit card using behavior.

\section{The Results on Linear regression and Testing $\mathrm{H} 4$}

The ANOVA test is conducted both on independent variable (Gender) and depended variable (Using credit limit) to justify the relationship between Gender and Using Credit limit. The result indicating that there is no significant relationship between genders and using the credit limit. As the $p$ value is 0.580 which is greater than .05 , thus, the result does not support the hypothesis that there is no significant difference in using credit card between male and female in Bangladesh. The reason could be the gender attitude in Bangladesh differs than India, middle-eastern and western countries due to culture, education, religious believes, earning capabilities and credit availability.

Table 8. ANOVA test result

\begin{tabular}{|c|c|c|c|c|c|c|}
\hline \multicolumn{7}{|c|}{ ANOVA $^{b}$} \\
\hline Model & & Sum of Squares & $\mathrm{df}$ & Mean Square & $\mathrm{F}$ & Sig. \\
\hline \multirow[t]{3}{*}{1} & Regression & .073 & 1 & .073 & .308 & $.580^{\mathrm{a}}$ \\
\hline & Residual & 92.192 & 391 & .236 & & \\
\hline & Total & 92.265 & 392 & & & \\
\hline \multicolumn{7}{|c|}{ a. Predictors: (Constant), Gender } \\
\hline \multicolumn{7}{|c|}{ b. Dependent Variable: Using credit limit } \\
\hline
\end{tabular}




\begin{tabular}{|c|c|c|c|c|c|c|}
\hline \multicolumn{7}{|c|}{ Coefficients $^{\mathrm{a}}$} \\
\hline \multirow[b]{3}{*}{ Model } & & \multirow{2}{*}{\multicolumn{2}{|c|}{ Unstandardized Coefficients }} & \multirow{2}{*}{\multicolumn{3}{|c|}{$\begin{array}{l}\text { Standardized } \\
\text { Coefficients }\end{array}$}} \\
\hline & & & & & & \\
\hline & & $\mathrm{B}$ & Std. Error & Beta & $\mathrm{t}$ & Sig. \\
\hline \multirow[t]{2}{*}{1} & (Constant) & .412 & .068 & & 6.056 & .000 \\
\hline & Gender & -.040 & .073 & -.028 & -.555 & .580 \\
\hline
\end{tabular}

\subsubsection{Profession and Credit Card Usage Behavior}

The below table portrayed the scenario of credit card using behavior by different professionals and how often they using their credit card. Most of the designated professionals (79\%) are using credit card frequently. However, these professionals are using (18\%) full credit limit frequently and $82 \%$ are using the partial credit limit frequently. On the contrary, $32 \%$ undesignated professionals are using their credit limit frequently. However, $68 \%$ out of 125 undesignated professional using full credit limit frequently (58\%). Additionally, $42 \%$ users are using their credit limit partially but frequently.

Table 9. The scenario of credit card using behavior by different professionals

\begin{tabular}{lllll}
\hline Profession & Using credit limit & How Frequently & Credit card users & Percentage (\%) \\
\hline Designated & Partial & Very frequently & 46 & 17 \\
& & Frequently & 118 & 44 \\
& \multirow{2}{*}{ Full } & Low frequently & 49 & 18 \\
& & Very frequently & 6 & 2 \\
& & Frequently & 42 & 16 \\
Total & Low frequently & 7 & 3 \\
Undesignated & \multirow{2}{*}{ Partial } & & $\mathbf{2 6 8}$ & $\mathbf{6 8}$ \\
& & Very frequently & 4 & 3 \\
& & Frequently & 11 & 9 \\
& Full & Low frequently & 17 & 14 \\
& & Very frequently & 9 & 7 \\
Total & Frequently & 83 & 66 \\
& & Low frequently & 1 & 1 \\
& & 125 & $\mathbf{3 2}$ \\
\hline
\end{tabular}

Frequency Table: Profession and usage behavior of revolving credit.

\section{The Results on Linear regression and Testing $\mathrm{H} 5$}

The analysis of variance test (ANOVA) on depended variable (How Frequently Using credit limit) and independent variable (Profession). The result indicates that there is a significant relationship between various professions and promptness of using the credit card. As the $p$ value is 0.000 which is lower than .05 , thus, the result supports the hypothesis that there is a significant relationship among different professions and frequently credit using behavior in Bangladesh. 
Table 10. ANOVA test result

\begin{tabular}{|c|c|c|c|c|c|c|}
\hline \multicolumn{7}{|c|}{ ANOVA $^{b}$} \\
\hline Model & & Sum of Squares & df & Mean Square & $\mathrm{F}$ & Sig. \\
\hline \multirow{3}{*}{1} & Regression & 10.507 & 1 & 10.507 & \multirow[t]{3}{*}{32.024} & \multirow[t]{3}{*}{$.000^{\mathrm{a}}$} \\
\hline & Residual & 128.287 & 391 & \multirow[t]{2}{*}{.328} & & \\
\hline & Total & 138.794 & 392 & & & \\
\hline \multicolumn{7}{|c|}{ a. Predictors: (Constant), Profession } \\
\hline \multicolumn{7}{|c|}{ b. Dependent Variable: How frequently using credit card } \\
\hline \multicolumn{7}{|c|}{ Coefficients $^{\mathrm{a}}$} \\
\hline \multirow[t]{2}{*}{ Model } & & \multicolumn{2}{|c|}{ Unstandardized Coefficients } & $\begin{array}{l}\text { Standardized } \\
\text { Coefficients }\end{array}$ & $\mathrm{t}$ & Sig. \\
\hline & & $\mathrm{B}$ & Std. Error & Beta & & \\
\hline \multirow{2}{*}{1} & (Constant) & 1.641 & .113 & & 14.518 & .000 \\
\hline & Profession & -.206 & .036 & -.275 & -5.659 & .000 \\
\hline
\end{tabular}

\subsubsection{Behavioral Approach toward Bill E-Repayment by Different Age Group}

The below table describes the statistics of different age and bill repayment attitudes by using modern technology. The survey reveals that younger (52\%) and middle aged users (36-55) are more using electronic kiosk, where as majority of middle aged $(63 \%)$ are using online to repay their credit card bill. Conversely, younger $(17 \%)$ and middle aged (40\%) users pay less attention to repay bill in person. Additionally, seniors are less attracted to electronic kiosk ( $1 \%)$ and online payment $(0 \%)$, but pay more attention to the conventional way.

Table 11. The statistics of different age and bill repayment attitudes by using modern technology

\begin{tabular}{llllllll}
\hline & & Percentage & & Percentage & & \multicolumn{2}{c}{ Percentage } \\
Age & Pay in the self service kiosk & $\%$ & Bank queue & $\%$ & Online bill payment & $\%$ & Total \\
\hline $25-35$ & 110 & 52 & 24 & 17 & 15 & 37 & 149 \\
$36-45$ & 86 & 56 & 79 & 40 & 26 & 63 & 191 \\
$46-55$ & 13 & 8 & 24 & 12 & 0 & 0 & 37 \\
$55+$ & 1 & 1 & 15 & 8 & 0 & 0 & 16 \\
Overall & $\mathbf{2 1 0}$ & $\mathbf{5 2}$ & $\mathbf{1 4 2}$ & $\mathbf{3 6}$ & 41 & $\mathbf{1 0}$ & $\mathbf{3 9 3}$ \\
\hline
\end{tabular}

Frequency Table: Age and Behavioral approach toward bill e-repayment.

\section{The Results on Linear regression and Testing H 6}

Variance analysis (ANOVA) is conducted on depended variable (age) and independent variable (bill repayment behavior). The result indicates that there is a significant relationship between age and various bill e-repayment methods. As the $\mathrm{p}$ value is 0.000 which is lower than .05 , thus, the result supports the hypothesis that there is a significant relationship between age and various bill e-repayment methods. 
Table 12. ANOVA test

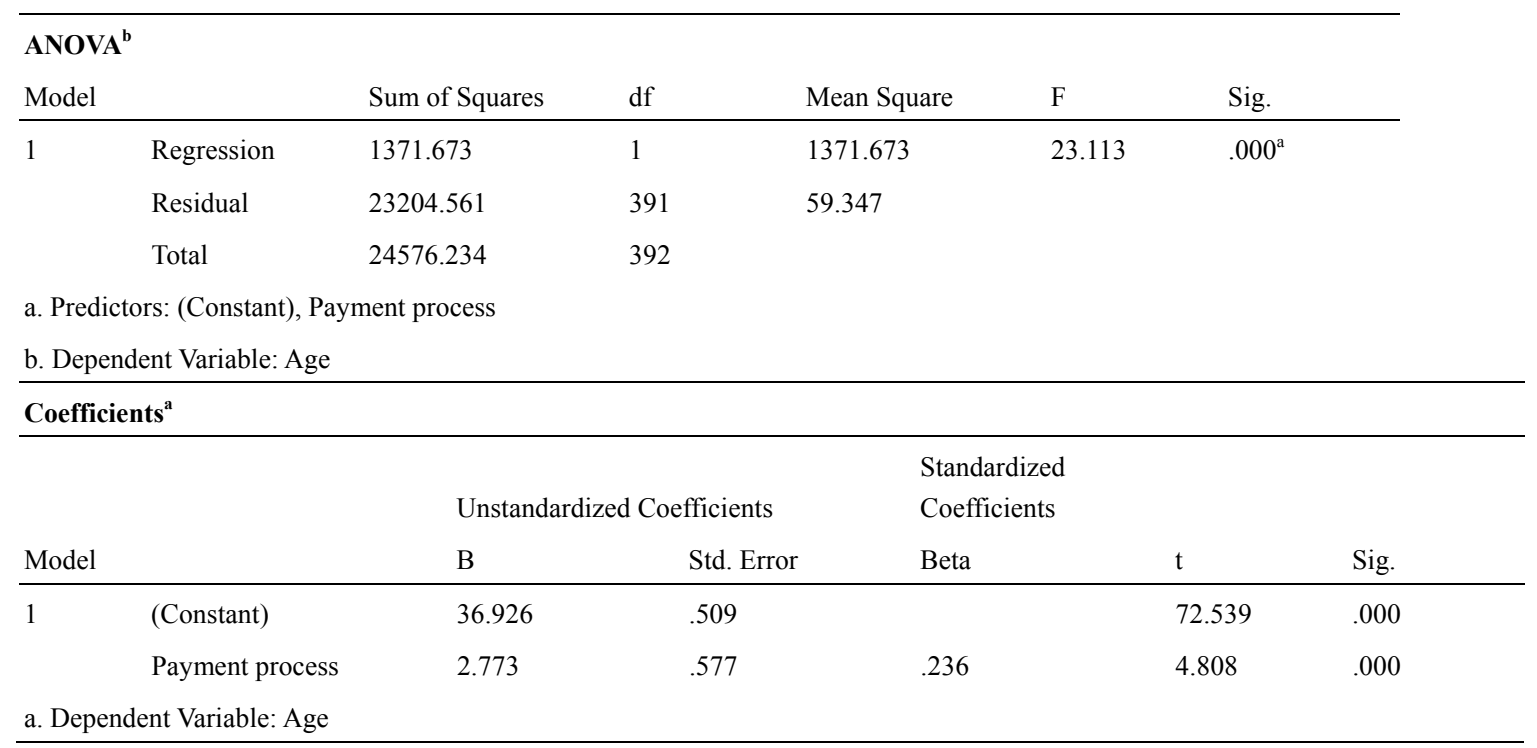

\subsection{Credit Card Features and Usages Behavior}

The table is representing the relationship among various features of credit card and using behavior. It indicates that more number of features of credit card are attracting users to use credit frequently. The survey result further revels that Discount offer (DO) is the most dominant features (49\%) followed by fund transfers (FT) and all other features. Interestingly, $19 \%$ users out of 393 are using credit card less frequently due to Cash Advance facility $(31 \%)$ as this features restrict them to use the credit card frequently.

Table 13. The relationship among various features of credit card and using behavior

\begin{tabular}{|c|c|c|c|c|c|c|c|c|}
\hline \multicolumn{2}{|c|}{ Using Very Frequently } & $\begin{array}{l}\text { Percentage } \\
(\%)\end{array}$ & Using & & $\begin{array}{l}\text { Percentage } \\
(\%)\end{array}$ & Using & & $\begin{array}{r}\text { Percentage } \\
(\%)\end{array}$ \\
\hline FPM & 0 & 00 & FPM & 11 & 4 & FPM & 2 & 3 \\
\hline $\mathrm{CAF}$ & 9 & 14 & $\mathrm{CAF}$ & 33 & 13 & $\mathrm{CAF}$ & 23 & 31 \\
\hline EC & 4 & 6 & $\mathrm{EC}$ & 1 & 00 & $\mathrm{EC}$ & 4 & 5 \\
\hline DO & 40 & 62 & DO & 116 & 46 & DO & 17 & 23 \\
\hline FT & 1 & 2 & FT & 32 & 13 & FT & 4 & 5 \\
\hline \multirow[t]{2}{*}{ All } & 11 & 17 & All & 61 & 24 & All & 24 & 32 \\
\hline & 65 & 17 & & 254 & 65 & & 74 & 19 \\
\hline
\end{tabular}

Frequency Table: Credit card features and usages behavior.

\section{The Results on Linear regression and Testing $\mathrm{H} 7$}

The analysis of variance test (ANOVA) on depended variable (How Frequently Using Credit Card) and independent variable (Various Credit Card Features). The ANOVA table reveals that there is no significant relationship among various features and promptness of using the credit card. Hence the $p$ value is 0.715 which is greater than .05 , thus, the result does not support the hypothesis that there is a significant relationship among different features and frequently credit using behavior in Bangladesh. As several features attracts the users to use the credit card frequently irrespective of all of the features which is supporting by the survey that only discount offers is the dominating features of using the credit card promptly. 
Table 14. ANOVA test result

\begin{tabular}{lllllll}
\hline $\begin{array}{l}\text { ANOVA }^{\mathbf{b}} \\
\text { Model }\end{array}$ & & Sum of Squares & Df & Mean Square & F & Sig. \\
\hline 1 & Regression & .274 & 1 & .274 & .134 & $.715^{\text {a }}$ \\
& Residual & 800.108 & 391 & 2.046 & & \\
& Total & 800.382 & 392 & &
\end{tabular}

a. Predictors: (Constant), How frequently using credit card

b. Dependent Variable: Features of cc

\begin{tabular}{|c|c|c|c|c|c|c|}
\hline \multicolumn{7}{|c|}{ Coefficients $^{\mathrm{a}}$} \\
\hline \multirow[b]{3}{*}{ Model } & & \multirow{2}{*}{\multicolumn{2}{|c|}{ Unstandardized Coefficients }} & \multirow{2}{*}{\multicolumn{3}{|c|}{$\begin{array}{l}\text { Standardized } \\
\text { Coefficients }\end{array}$}} \\
\hline & & & & & & \\
\hline & & $\mathrm{B}$ & Std. Error & Beta & $\mathrm{t}$ & Sig. \\
\hline \multirow[t]{2}{*}{1} & (Constant) & 3.175 & .144 & & 22.105 & .000 \\
\hline & How frequently using credit card & -.044 & .121 & -.019 & -.366 & .715 \\
\hline
\end{tabular}

\subsection{Behavioral Influence to Use a Credit Card}

The below table explore the internal and external influential factors that effects on credit card using behavior. It reveals that external factors $(77 \%)$ are more influential than internal factors $(23 \%)$ to use credit card in Bangladesh. In addition to, external influences (84\%) are the major persuading factors that motivate credit card users to use credit card frequently.

Table 15. Explore the internal and external influential factors

\begin{tabular}{lllll}
\hline Usage Patterns & II & Percentage (\%) & EI & Percentage (\%) \\
\hline Very frequently & 14 & 16 & 51 & 17 \\
Frequently & 50 & 56 & 204 & 67 \\
Low frequently & 25 & 28 & 49 & 16 \\
Overall & $\mathbf{8 9}$ & $\mathbf{2 3}$ & $\mathbf{3 0 4}$ & $\mathbf{7 7}$ \\
\hline
\end{tabular}

Frequency Table: Behavioral influence to use a credit card.

\section{The Results on Linear regression and Testing $\mathrm{H8}$}

The analysis of variance test (ANOVA) on depended variable (How Frequently Using Credit Card) and independent variable (Behavioral Influence). This study divulges that there is no significant relationship between behavioral influences and how frequently using the credit card. Hence the $p$ value is 0.069 which is greater than .05 , thus, the result does not support the hypothesis that external factors are more influencing credit card users to spend money through credit cards in Bangladesh. As how frequently using the credit merely depends on external factors, rather it depends on the necessity of the users. 
Table 16. ANOVA test result

\begin{tabular}{lllllll}
\hline ANOVA $^{\mathbf{b}}$ & \multicolumn{1}{l}{} & & \\
\hline Model & & Sum of Squares & $\mathrm{df}$ & Mean Square & $\mathrm{F}$ & Sig. \\
1 & Regression & 1.167 & 1 & 1.167 & 3.314 & $.069^{\mathrm{a}}$ \\
& Residual & 137.627 & 391 & .352 & & \\
& Total & 138.794 & 392 & &
\end{tabular}

a. Predictors: (Constant), Behavioral influence to use a cc

b. Dependent Variable: How frequently using credit card

\begin{tabular}{|c|c|c|c|c|c|c|}
\hline \multirow[b]{3}{*}{ Model } & & \multicolumn{5}{|c|}{ Standardized } \\
\hline & & \multicolumn{2}{|c|}{ Unstandardized Coefficients } & \multicolumn{3}{|c|}{ Coefficients } \\
\hline & & $\mathrm{B}$ & Std. Error & Beta & $\mathrm{t}$ & Sig. \\
\hline 1 & (Constant) & 1.124 & .063 & & 17.867 & .000 \\
\hline & Behavioral influence to use a cc & -.130 & .072 & -.092 & -1.821 & .069 \\
\hline
\end{tabular}

\section{Conclusion}

Credit card is one of the most convenient financial instruments of revolving credit across the globe. Bangladesh is an emerging country that started using credit by mid 90s at narrow level. After two decades credit cards are getting more popular financial product among the various users, in spite of comparatively high interest rate and strict using terms and conditions compare to other financial products. However, usage behavior of credit cards vary across the globe based on various demographic patterns. Empirical studies show that there is a significant difference among developed and developing economies. Along with, empirical research concludes that country variations like middle-eastern, Indian-subcontinent, Malaysia and so on, have greater variations in using credit card behavior. This study attempts to analyse credit card usage behavior in emerging country like Bangladesh. To conduct the research, the researchers attempt to follow triangulation approach to justify the credit card usage behavior by considering 500 respondents as target population of which 393 respondents response positively. To analyse data which is collected from survey the research used Microsoft excel and SPSS as statistical tools. To justify the behavioral approach of using credit card this study develops hypothesis based on earning capabilities with demographic behavioral patterns (sex, age, profession, religious believe, education level, income, marital status, culture and attitude towards debt) and usage behavior. This research concludes that higher earners have greater tendency to use more revolving credit. It further reveals that demographic patterns of using credit card in Bangladesh vary significantly: age-credit card repayment attitude, behavioral approach toward bill e-repayment; gender-using revolving credit; profession-usage behavior of revolving credit; credit card features and usage behavior; behavioral influence to use credit card.

\section{References}

Abdul-Muhmin, A. G., \& Umar, Y. A. (2007). Credit card ownership and usage behaviour in Saudi

Adcock, W. O., Hirschman, E. C., \& Goldstucker, J. L. (1997). Bank Credit Card Users: An Update Profile. Advances in Consumer Research, 4, 236-241.

Arabia. (n.d.). The impact of demographics and attitudes towards debt. Journal of Financial Services Marketing, 12(3), 219-235. http://dx.doi.org/10.1057/palgrave.fsm.4760074

Arabzadeh, E., \& Aghaeian, S. (2015). The relationship of usages and Management of credit cards on lifestyles and purchasing behaviours of Cardholders. International Journal of Management Research and Business Strategy, 4(3), 245-256.

Cameron, S., \& Price, D. (2009). Business Research Methods- A Practical Approach (1st ed.) Chartered Institute of Personnel \& Development. 
Conner, M., \& Armitage, C. J. (1998). Extending the theory of planned behavior: A review of avenues for further research. Journal of Applied Social Psychology, 28, 1429-1464.

Cooper, D. R., \& Schindler, P. S. (2003). Business Research Methods (8th ed.). Boston: 15 McGraw-Hill Irwin.

Dewri, L., Islam, R., \& Zamman, S. M. A. (2015). Behavioral analysis of investors' attitude towards dividend declaration in developing country-A case of Bangladesh. International Journal of Business and Management (IJBM), 10(11), 185-198. http://dx.doi.org/10.5539/ijbm.v10n11p185

Eysenck, M. et al., (2000). Cognitive psychology: A student's handbook (4th ed.) London: Lawrence Erlbaum.

Foscht, T., Maloles, III. C., Swoboda, B., Morschett, D., \& Sinha, I. (2008). The impact of culture on brand perception: a six-nation study. Journal of Product and Brand Management, 17(3), 131-142.

Friedman, M. (1957). A theory of the consumption function. Princeton, NJ: Princeton University Press.

Gan, L. L., Maysami, R. R. C., \& Koh, H. C. (2008). Singapore credit cardholders: ownership usage patterns and perceptions. Journal of Services Marketing, 22(4), 267-279. http://dx.doi.org/10.1108/08876040810881678

Godwin, D. D. (1998). Household debt quintiles: Explaining changes 1983-1989. The Journal of Consumer Affairs, 32(2), 369-393.

Hazembuller, A. T., Lombardi, B. A., \& Hogarth, J. M. (2007). Unlocking the risk-based pricing puzzle: Five keys to cutting credit card costs. Consumer Interests Annual, 53, 73-84.

Kahneman, D. et al. (1979). Prospect Theory: An Analysis of Decision under Risk. Econometrica, 47(2) 263-291.

Katz, J. (1997). The joy of consumption. Federal Reserve Bank of Boston Regional Review, 7(1), 12-17.

Kaynak, E., \& Harcar, T. (2001). Consumer's attitudes and intentions towards credit card usage in an advanced developing country. Journal of Financial Services Marketing, 6(1), 24. http://dx.doi.org/10.1108/08876049510094496

Kaynak, E., Yucelt, U., \& MacGregor, R. M. (1986). Attitudinal and behavioral characteristics of American and Canadian credit card holders. Journal of Professional Services Marketing, 1(3), 101-119.

Khare, A., \& Singh, S. (2011). Factors affecting credit card use in India. Asia Pacific Journal of Marketing and Logistics, 24(2), 236-256. http://dx.doi.org/10.1108/13555851211218048

Kim, H., \& DeVaney, S. A. (2001). The determinants of outstanding balances among credit card revolvers. Financial Counseling and Planning, 12(1), 67-77.

Kurtulu, K., \& Nasir, S. (2006). Consumer Behavior of Credit card Users in an Emerging Market. 6th Global Conference on Business \& Economics, Gutman Conference Center, USA.

Norum, P. S. (2008). The role of time preference and credit card usage in compulsive buying behaviour. $\begin{array}{lllll}\text { International Journal of Consumer } & \text { Studies, } & 32, & \text { 269-275. }\end{array}$ http://dx.doi.org/10.1111/j.1470-6431.2008.00678.x

Peterson, M. (2007). Effects of income, assets and age on the vacationing behavior of U.S. consumers. Journal of Vacation Marketing, 13(1), 29-43.

Robb, Cliff, A. (2011). Financial Knowledge and Credit Card Behaviour of College Students. Journal of Family and Economic Issues. http://dx.doi.org/10.1007/s10834-011-9259-y

Roberts, J. A., \& Jones, E. (2001). Money attitudes, credit card use, and compulsive buying among American college students. Journal of Consumer Affairs, 35(21), 213-240.

Rutherford, Leann G., \& DeVaney, S. A. (2009). Utilizing the Theory of Planned Behavior to Understand Convenience Use of Credit Cards. Journal of Financial Counseling and Planning, 20(2), 48-63.

Schiffman, L. G. et al. (2007). Consumer Behavior (9th ed.). New Jersey: Prentice Hall.

Schwarz, N. (2003). Self-reports in consumer research: The challenge of comparing cohorts and cultures. Journal of Consumer Research, 29(4), 588-594.

Simon, H. (1991). Models of my Life. New York: Basic Books; Harper Collins.

Skinner, B. F. (1938). The behavior of organisms. An Experimental Analysis. New York: Appleton-Century.

Themba, G., \& Tumedi, C. B. (2012). Credit Card Ownership and Usage Behaviour in Botswana. International Journal of Business Administration, 3(6), 60-71. 
Thomas, F., Maloles, III. C., \& Swoboda, B. (2010). Debit and credit card usage and satisfaction: Who uses which and why-evidence from Austria. International Journal of Bank Marketing, 28(2), 150-165.

Watson, J. et al. (1920). Conditioned Emotional Reactions. Journal of Experimental Psychology, 3(1), 1-14.

Wickramsinghe, V., \& Gurugamage, A. (2009). Consumer credit card ownership and usage practices: empirical evidence from Sri Lanka. International Journal of Consumer Studies, 33, 436-447. http://dx.doi.org/10.1111/j.1470-6431.2009.00779.x

\section{Copyrights}

Copyright for this article is retained by the author(s), with first publication rights granted to the journal.

This is an open-access article distributed under the terms and conditions of the Creative Commons Attribution license (http://creativecommons.org/licenses/by/3.0/). 